\title{
PENGARUH VIRAL MARKETING DAN BRAND AWARENESS TERHADAP NIAT BELI PADA BURGER KING INDONESIA
}

\author{
Agatha Christy Avega Dumatri \\ Universitas Negeri Surabaya \\ avegatha@gmail.com \\ Tias Andarini Indarwati \\ Universitas Negeri Surabaya \\ tiasindarwati@unesa.ac.id
}

\begin{abstract}
Competition for fast food restaurants is so fierce that companies need to find ways to do marketing wisely. Social media is one of the growing platforms that can be used as a marketing medium to reach consumers widely and quickly, which will lead to the emergence of consumer purchase intentions. This study aims to examine the effect of viral marketing and brand awareness on purchase intention. This study used 200 respondents with non-probability sampling techniques, and the method used was judgmental sampling were distributed using online questionnaires. Data were analyzed using multiple linear regression. This study found that viral marketing and brand awareness have a significant influence on purchase intention "Burger King Indonesia". Based on the result, it can be used as a recommendation "Burger King Indonesia" in increase brand awareness more among competitors and have an impact to purchase intention.
\end{abstract}

Keywords: brand awareness; burger king; fast food restaurant; viral marketing; purchase intention

\section{PENDAHULUAN}

Perusahaan saat ini dapat membagikan informasi tentang produk maupun jasa dengan menggunakan media sosial, hal ini akan lebih cepat dan hemat biaya (SI, 2016). Menurut Kemp (2020), jumlah pengguna instagram di Indonesia sebanyak $79 \%$ dari pengguna internet di Indonesia yang berjumlah 175,4 juta jiwa penduduk. Penggunaan internet yang pesat sejalan dengan penggunaan media sosial, salah satu platform yang banyak diakses dan memiliki tingkat pengguna aktif yang tinggi yakni aplikasi instagram. Instagram merupakan media sosial yang menyediakan berbagai fitur, serta dapat membagikan cerita melalui foto dan video untuk keperluan pribadi hingga berbisnis dan didominasi oleh pengguna usia golongan produktif (www.goodnewsfromindonesia.id, 2020).

Tahun 2020 pertumbuhan ekonomi Indonesia menurun, hal ini terjadi akibat adanya pandemi, hingga kuartal II tahun 2020 menjadi -5,32\% (www.money.kompas.com, 2020). Sejak pandemi Covid-19 berlangsung di Indonesia, kegiatan masyarakat saat ini banyak melakukan pekerjaan di rumah untuk menghindari penularan virus corona. Hal tersebut berdampak pada hampir semua sektor industri, salah satunya industri makanan (bisnis.tempo.co, 2020). Sehingga perusahaan perlu melakukan pemasaran terbaik yang mampu menaikkan omzet penjualan dimasa pandemi ini, salah satu yang menarik dilakukan oleh restoran cepat saji yaitu Burger King Indonesia yang membuat unggahan pada media sosial instagram resminya. Unggahan tanggal 3 November 2020, yang berjudul "Pesanlah dari Mcdonald's" sampai dengan saat ini unggahan tersebut telah disukai sebanyak 350.084 dan dikomentari sebanyak 13.361 oleh pengguna instagram. Unggahan tersebut menjadi viral, terbukti dengan trending di platform twitter dan menjadi headline pada beberapa platform berita (www.pikiran-rakyat.com, 2020). Di mana trending topik apabila topik tersebut diperbincangkan hanya pada satu platform dan waktunya terbatas sedangkan viral muncul diberbagai lintas platform seperti instagram, twitter, facebook, youtube, dan lain-lain (www.shukanbunshun.com, 2019).

Burger King Indonesia melakukan pemasaran dengan cara menyarankan pelanggan untuk juga membeli pada merek lain, hal ini membuat unggahan Burger King Indonesia menjadi viral di media sosial (cnbcindonesia.com, 2020). Kata viral menurut Kamus Besar Bahasa Indonesia yaitu berkaitan dengan sesuatu yang menyebar dengan cepat dan luas seperti virus. Berdasarkan data Top Brand 
Agatha Christy Avega Dumatri \& Tias Andarini Indarwati. Pengaruh Viral Marketing dan Brand Awareness terhadap Niat Beli pada Burger King Indonesia

Award pada kategori Top Brand Indeks for Kids dan Teens, mulai tahun 2019 Burger King Indonesia berada pada peringkat ke-5 dan pada tahun 2020 mengalami peningkatan persentase (www.topbrandaward.com, 2019). Pemasaran inovatif yang telah dilakukan Burger King Indonesia hingga menjadi viral, namun belum menjadikan Burger King berada pada peringkat pertama dalam Top Brand Indeks 2020. Selain itu tujuan dalam pemasaran yang viral tersebut adalah memunculkan niat beli masyarakat agar membeli produk Burger King Indonesia, dikarenakan selama pandemi masyarakat menghindari membeli makanan di luar (finance.detik.com, 2020).

Niat beli konsumen dipengaruhi oleh beberapa faktor yang salah satunya adalah viral marketing (Liu \& Wang, 2019). Liu \& Wang (2019), menyebutkan viral marketing merupakan pesan yang menyebar secara cepat melalui jaringan internet dan secara eksponensial. Pemasaran viral yang dilakukan perusahaan dengan menyebarkan pesan melalui e-mail, blog dan lain-lain kepada konsumen dengan ini maka akan terjalin interaksi anatara perusahaan dan konsumen, serta dapat terjalin pertukaran informasi antar konsumen (Trivedi, 2017). Pada penelitian terdahulu penggunaan viral marketing menggunakan media sosial dengan produk budaya yaitu batik berpengaruh signifikan terhadap niat beli (Satrio et al., 2020). Viral marketing yang dilakukan toko retail dengan menggunakan media sosial juga memberikan hasil positif terhadap niat beli (Rukuni et al., 2017). Penggunaan instagram saat ini menjadi platform media sosial yang memiliki berbagai fitur yang dapat memudahkan penggunaan pribadi, pebisnis maupun perusahaan (www.goodnewsfromindonesia.id, 2020).

Brand awareness juga menjadi faktor penentu konsumen untuk memilih sesuatu yang akan dikonsumsi (Susilowati \& Sari, 2020). Dari berbagai jenis merek makanan fast food yang ada di Indonesia maka ada berbagai banyak pilihan untuk konsumen. Hal tersebut perlu disoroti perusahaan untuk membangun brand awareness dengan baik agar konsumen mampu mengenali merek tersebut di antara berbagai merek sejenis yang ada (Susilowati \& Sari, 2020). Lee \& Goh (2019) menyatakan brand awareness berpengaruh signifikan terhadap niat beli, di mana setiap komunikasi dan transaksi tidak akan terjadi jika tidak ada kesadaran merek. Kemudian Soewandi (2015) menyatakan brand awareness berpengaruh signifikan terhadap niat beli, dengan membangun kesadaran merek melalui media sosial perusahaan dapat mengarahkan niat beli konsumen dalam membeli produk yang ditawarkan perusahaan. Hal ini berbeda dengan beberapa hasil penelitian Walangitan et al. (2015), Suryadi (2015) dan Koliby \& Rahman (2018), brand awareness tidak berpengaruh terhadap niat beli.

Penelitian ini bertujuan untuk mengetahui adanya pengaruh viral marketing dan brand awareness terhadap niat beli pada Burger King Indonesia. Oleh sebab itu, diharapkan penelitian ini mampu memberikan kontribusi agar Burger King Indonesia dapat mengembangkan pemasaran produk maupun layanannya.

\section{KAJIAN PUSTAKA DAN PENGEMBANGAN HIPOTESIS}

\section{Viral Marketing}

Kotler \& Keller (2016:647) mendefinisikan viral marketing adalah versi internet dari pemasaran mulut-ke-mulut atau konten pemasaran yang melibatkan konsumen ingin menyebarkannya kepada orang lain. Penyebaran viral marketing seperti virus pesan yang menyebar cepat dengan kata-kata dari orang ke orang lainnya, di mana konsumen sendiri yang memilih membagikan pesan tersebut (Liu \& Wang, 2019). Adapun dua jenis viral marketing, yaitu amplified viral marketing dan organic viral marketing. Amplified viral marketing adalah pemasaran yang direncanakan oleh pemasar dari perusahaan atau organisasi, yang dapat diatur oleh pemasar. Sedangkan organic viral marketing yaitu promosi pemasaran yang tidak dapat dikendalikan, yang menyebar di antara konsumen (word of mouth) tanpa bantuan dari pemasar, di mana konsumen sendiri yang membuat dan membagikannya secara sukarela (Stokes, 2012).

Iklan viral dan E-WOM merupakan atribut dari variabel viral marketing (Trivedi, 2017). Dalam melakukan viral marketing terutama pada media sosial membutuhkan pesan yang menarik (blog, buletin, video, dan lain-lain) yang disajikan dalam konteks online. Hal ini mencakup strategi dan tindakan pemasaran online yang bertujuan untuk mengidentifikasi konsumen yang bersedia 
meneruskan pesan tersebut kepada anggota jejaring sosial mereka, untuk disebarluaskan seperti virus (Petrescu, 2014:03). Rukuni (2017) menyatakan bahwa indikator viral marketing yang digunakan untuk mengukur viral marketing, ialah informativeness, entertainment, irritation dan source credibility. Sedangkan Motwani \& Haryani (2018) menyatakan bahwa terdapat 7 indikator yang digunakan untuk mengukur viral marketing yaitu immerse effieacy, supportive access, professed security, message clarity, irrepressible, consumer dependency dan escalating brand.

\section{Brand awareness}

Perilaku konsumen, preferensi, dan kebutuhan harus diidentifikasi dengan baik dan memahami desain produk yang dapat memuaskan konsumen, hal ini dapat membangun ekuitas merek yang kuat. Hal ini dapat menjadi langkah penting untuk memerangi persaingan yang ketat dan menonjol di antara pesaing, salah satu elemen paling penting dari ekuitas merek adalah kesadaran merek (Lee \& Goh, 2019). Menurut Kotler \& Keller (2016:179) brand awareness atau kesadaran merek adalah kemampuan mengidentifikasi suatu merek dalam kategori dengan cukup rinci sehingga dapat melakukan pembelian dan merupakan dasar dari ekuitas merek. Sedangkan menurut Susilowati \& Sari (2020), brand awareness yaitu kemampuan konsumen mengenali dan mengingat suatu merek seperti logo, nama merek, atau symbol. Menurut Aaker (dalam Durianto, dkk, 2004:55) kesadaran merek merupakan pengetahuan konsumen akan suatu merek. Terdapat 4 tingkatan brand awareness yaitu level paling tinggi adalah top of mind pada tahap ini konsumen memiliki ingatan utama terhadap suatu merek di antara merek sejenis, tahap ini adalah yang paling diharapkan perusahaan agar konsumen mengenali merek mereka dengan mudah di antara merek sejenis, kemudian terdapat tahapan brand recall merupakan tahapan level konsumen mampu mengingat merek tanpa diberikan dorongan atau pengingatan sebelumnya namun tidak menjadikan merek tersebut pilihan utama, selanjutnya tahapan brand recognition yakni tahapan level konsumen mampu mengenali suatu merek dengan bantuan seperti gambar atau logo dari suatu merek, dan terakhir pada tahap unaware of brand di mana merupakan level terbawah dalam kesadaran merek, dalam posisi ini konsumen tidak yakin mengenali suatu merek, dari menu maupun logo dan tahap ini yang paling dihindari oleh perusahaan (Yoo et al., 2000).

\section{Niat Beli}

Niat beli merupakan niat konsumen untuk membeli suatu produk atau layanan (Liu \& Wang, 2019). Pada umumnya niat beli dilakukan konsumen setelah mendapat informasi eksternal, salah satunya ketika konsumen mengetahui atau mendapat pesan viral marketing. Apabila konsumen tertarik maka akan memiliki niat untuk membeli suatu produk atau layanan tersebut (Satrio et al., 2020). Menurut Kotler \& Keller (2016:200) definisi niat beli adalah tindakan secara online maupun offline yang dilakukan konsumen untuk suatu produk yang ingin dibeli dan berdasarkan atas pengetahuan tentang suatu merek. Ada berbagai pilihan yang ditawarkan oleh berbagai perusahaan di bidang yang sama dengan pilihan produk yang berbeda, niat beli konsumen ini menentukan apakah konsumen akan membeli produk tersebut atau tidak (Walangitan et al., 2015).

Menurut Liu \& Wang (2019) untuk mengukur niat beli dapat menggunakan faktor yang dapat memengaruhi pembelian produk yaitu niat untuk membeli berdasarkan informasi dari internet, niat untuk membeli berdasarkan konten viral marketing dan niat untuk membeli berdasarkan pesan viral marketing yang diterima.

\section{Hubungan antar Variabel}

Berdasarkan Sawaftah et al. (2019), viral marketing menggambarkan peran yang berguna dalam mengubah niat beli konsumen, dengan menggunakan alat atau teknik yang berbeda dan penggunaan teknologi. Target utama dari proses tersebut, terkait dengan adaanya keberadaan konsumen di media sosial. Sumber viral marketing harus dapat dipercaya, hal ini dapat mendukung orang-orang untuk sukarela menyebarkan pesan ke orang lain dengan memastikan situs viral marketing tersebut dapat dipercaya (Motwani \& Haryani, 2018). Rukuni et al. (2017) mengemukakan viral marketing harus mengandung pesan informatif tentang produk atau layanan yang berguna bagi pelanggan. Menurut Liu dan Wang (2019), viral marketing yang dilakukan dari perusahaan dapat berpengaruh signifikan 
Agatha Christy Avega Dumatri \& Tias Andarini Indarwati. Pengaruh Viral Marketing dan Brand Awareness terhadap Niat Beli pada Burger King Indonesia

terhadap niat beli. Hal ini sejalan dengan hasil penelitian yang dilakukan oleh Satrio et al. (2020), viral marketing berpengaruh signifikan terhadap niat beli.

H1 : Viral marketing berpengaruh signifikan terhadap niat beli.

Brand awareness merupakan elemen penting yang dapat sebagai pendorong memengaruhi tindakan seseorang untuk melakukan niat beli (Susilowati \& Sari, 2020). Kesadaran merek adalah hal penting, tanpa adanya kesadaran merek, tidak akan ada niat beli konsumen untuk membeli suatu produk atau layanan (Lee \& Goh, 2019). Dengan persaingan industri yang semakin ketat saat ini perusahaan perlu membangun kesadaran merek yang kuat untuk memerangi kompetisi dan menonjol di antara merek sejenis, dengan memahami desain produk yang dapat memuaskan konsumen. Pada umumnya kesadaran merek muncul dari dua jenis pengalaman, secara langsung apabila konsumen telah membeli produk atau secara tidak langsung mencakup iklan atau pemasaran yang dilakukan perusahaan (Koliby \& Rahman, 2018). Menurut Suryadi (2015), tujuan paling utama kesadaran merek adalah menempatkan merek ada diurutan pertama dalam pikiran konsumen. Penelitian yang dilakukan oleh Soewandi (2015) mengemukakan brand awareness berpengaruh signifikan terhadap niat beli.

$\mathrm{H} 2$ : Brand awareness berpengaruh signifikan terhadap niat beli.

Berdasarkan hipotesis yang telah ditetapkan, diperoleh kerangka konseptual pada Gambar 1.

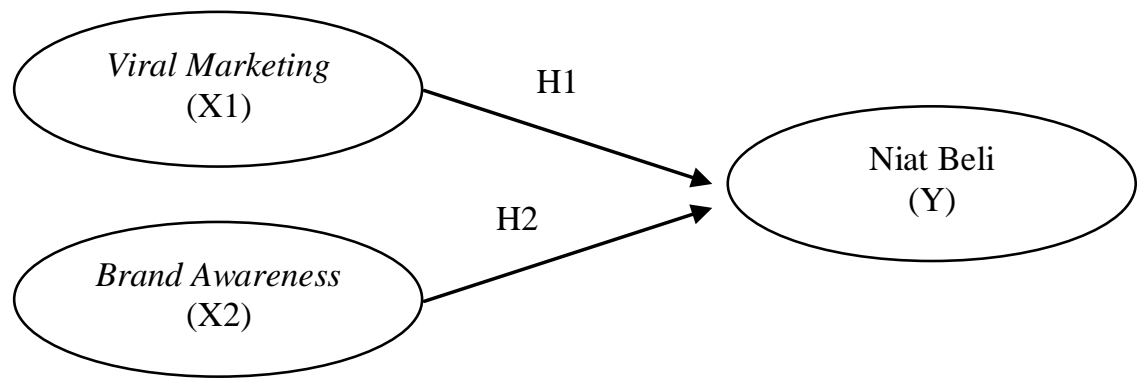

Gambar 1. KERANGKA KONSEPTUAL

\section{METODE PENELITIAN}

Jenis penelitian yang digunakan adalah penelitian kuantitatif. Karakteristik responden yaitu orangorang yang mengetahui tentang postingan "Pesanlah dari McDonlads" pada instagram Burger King Indonesia dan minimal berusia 19 tahun. Responden sebanyak 200 orang. Menggunakan teknik non probability sampling dengan metode judgemental sampling. Pengukuran menggunakan skala likert lima kategori. Indikator yang digunakan untuk mengukur viral marketing, merujuk dari Wiludjeng \& Nurlela (2013) yaitu affection altruism, curiosity, content consumption dan content forwarding dengan pertimbangan penyesuaian dari objek yang diteliti. Pengukuran brand awareness yang digunakan merujuk pada Yoo et al. (2000) dengan top of mind (merek yang paling diingat konsumen). brand recall (kemampuan konsumen mengingat kembali merek), brand recognition (konsumen mengenal merek setelah diberikan pengingatan kembali), terakhir unaware of brands (tidak yakin mengenali suatu merek). Menurut Satrio et al. (2020) indikator dari niat beli adalah purchase intention, dan purchase recommendation. Menurut Martins et al. (2017), indikator niat beli adalah berencana untuk membeli dan berkeinginan untuk membeli. Indikator variabel niat beli yang digunakan pada penelitian ini menggunakan dari Satrio et al. (2020) dan Martins et al. (2017) dengan pertimbangan penyesuaian dengan objek yang diteliti dan mengurangi pernyataan yang ambigu.

Teknik analisis data menggunakan regresi linier berganda. Item pertanyaan diadopsi dari penelitian sebelumnya pada tabel 1 . 
Tabel 1.

ITEM PENGUKURAN VARIABEL

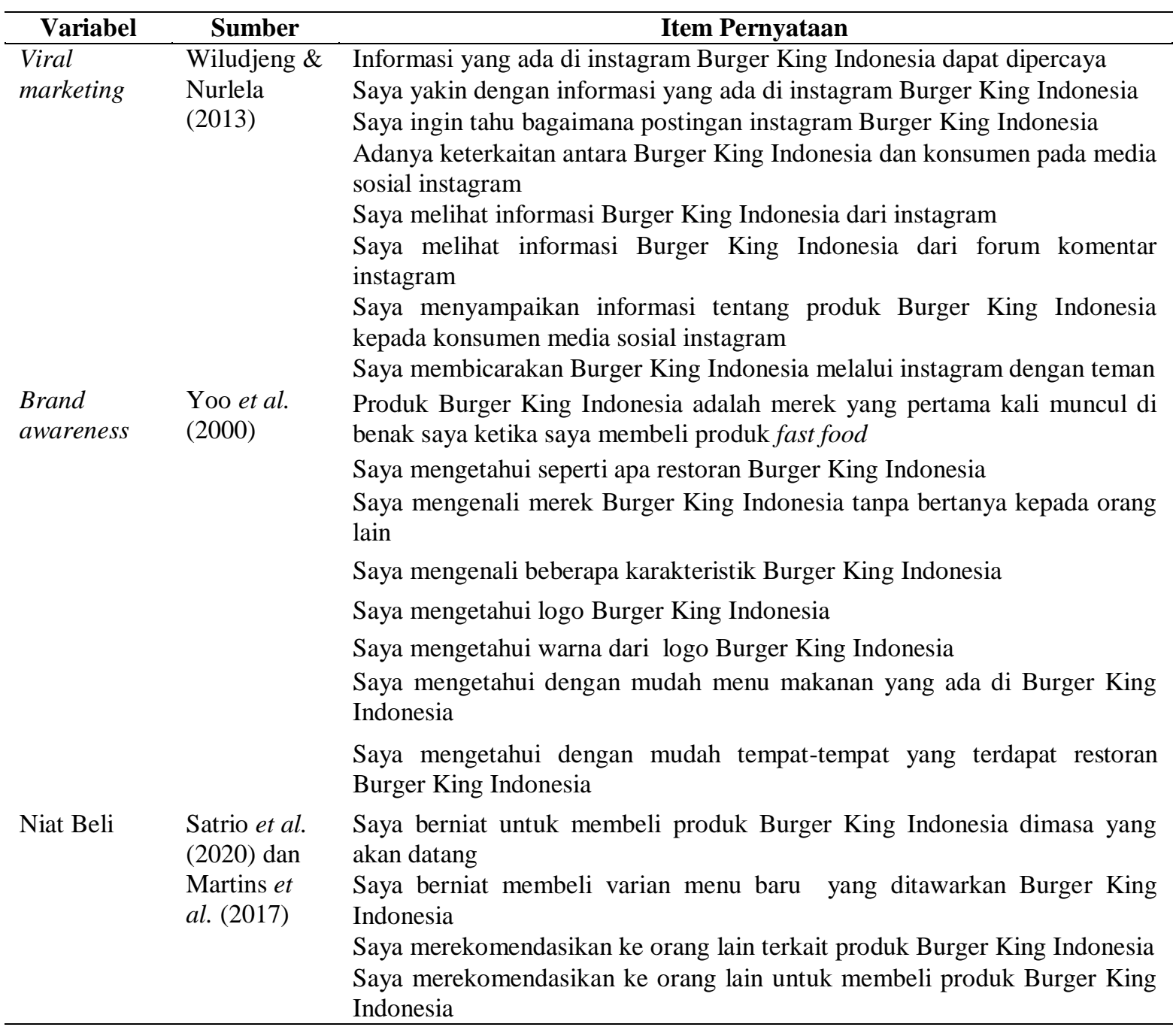

Sumber :data diolah peneliti (2020)

\section{HASIL DAN PEMBAHASAN}

\section{Hasil Uji Validitas dan Reliabilitas}

Item pernyataan dilakukan uji validitas dan reliabilitas sebelumnya. Berdasarkan olah data hasil uji validitas menunjukkan bahwa nilai Corrected Item - Total Correlation lebih besar dari nilai $r$ tabel yaitu 0,361 ,sehingga semua item pernyataan dalam penelitian ini dinyatakan valid untuk digunakan sebagai alat ukur. Uji reliabilitas, semua variabel memiliki nilai Cronbach's Alpha lebih besar dari 0,70 . Sehingga item pernyataan variabel dinyatakan reliabel dan dapat digunakan sebagai alat ukur variabel viral marketing, brand awareness dan niat beli.

\section{Hasil Uji Asumsi Klasik}

Persyaratan uji regresi linier yang digunakan terdiri dari uji normalitas dengan Kolmogorov-Smirnov Test dilihat pada nilai asymp sig. (2-tailed) memiliki hasil nilai signifikansi sebesar 0,200. Hasil uji normalitas ini memenuhi asumsi karena nilai signifikansi lebih besar dari 0,05 dan data berdistribusi normal. Persyratan uji lainnya yaitu uji multikolinieritas dengan hasil nilai tolerance dari viral marketing dan brand awareness yaitu $0,736 \geq 0,01$. Nilai VIF (Variance Inflation Factor) dari viral marketing dan brand awareness yaitu $1.358 \leq 10$. Artinya data tidak terjadi multikolinieritas. Persyarat uji yang terakhir menggunakan uji heterokedasitas, dengan menggunakan Spearman's rho 
Agatha Christy Avega Dumatri \& Tias Andarini Indarwati. Pengaruh Viral Marketing dan Brand Awareness terhadap Niat Beli pada Burger King Indonesia

hasil koefisien menunjukkan nilai signifikansi pada variabel viral marketing sebesar 0,613 dan signifikansi pada variabel brand awareness sebesar 0,765. Hasil pada masing-masing variabel dengan residual lebih besar dari 0,05 yang artinya tidak terjadi heteroskedastisitas.

\section{Karakteristik Responden}

Total responden sebanyak 200 responden. Mayoritas responden memiliki usia 19 - 29 tahun sebesar $88 \%$ dan didominasi oleh wanita sebesar $69,5 \%$. Berdasarkan pekerjaan yang mendominasi adalah pelajar/mahasiswa sebanyak 63\%. Hal ini juga sesuai pada karakteristik lainnya yang mendominasi yaitu status lajang terdapat 85,5\%, berpendidikan terakhir SMA terdapat 66,5\% dan 43,5\% dengan pengeluaran kurang dari Rp1.000.000. Berdasarkan karakteristiknya, mayoritas wanita memiliki rentang usia 19 - 29 tahun dengan status pelajar/mahasiswa. Apabila dikaitkan golongan repsonden tersebut sangat bergantung dan mengandalkan kecanggihan teknologi, salah satunya dengan penggunaan instagram untuk mendapatkan referensi, ataupun memberikan referensi tentang pilihan restoran fast food dan promo menu makanan dari restoran akan menjadi acuan bagi calon pembeli.

Tabel 2.

KARAKTERISTIK RESPONDEN

\begin{tabular}{llcc}
\hline & Karakteristik Responden & Jumlah & Presentase (\%) \\
\hline Usia & 19-29 Tahun & 175 & $88 \%$ \\
& 30-40 Tahun & 20 & $10 \%$ \\
& 41-51 Tahun & 3 & $1 \%$ \\
Jenis Kelamin & 51 Tahun & 2 & $1 \%$ \\
Status Perkawinan & Pria & 61 & $30,5 \%$ \\
& Wanita & 139 & $69,5 \%$ \\
Pendidikan Terakhir & Lajang & 171 & $85,5 \%$ \\
& Kawin & 29 & $14,5 \%$ \\
& SMA & 133 & $66,5 \%$ \\
& Diploma & 15 & $7,5 \%$ \\
Pekerjaan & Sarjana & 47 & $23,5 \%$ \\
& Lainnya & 5 & $2,5 \%$ \\
& Pelajar/Mahasiswa & 126 & $63 \%$ \\
& PNS & 3 & $1,5 \%$ \\
& Pegawai Swasta & 33 & $16,5 \%$ \\
& Ibu Rumah Tangga & 6 & $3 \%$ \\
Pengeluaran Per Bulan & 32 & $16 \%$ \\
& Lainnya & 87 & $43,5 \%$ \\
& Kurang dari Rp.1.000.000 & 48 & $24 \%$ \\
& Rp.1.000.001-Rp.1.500.000 & 23 & $11,5 \%$ \\
& Rp.1.500.001-Rp.2.000.000 & 22 & $11 \%$ \\
& Rp.2.000.001-Rp.3.000.000 & 14 & $7,5 \%$ \\
& Rp.3.000.001-Rp.5.000.000 & 3 & $1,5 \%$ \\
& Rp.5.000.001-Rp.7.000.000 & 3 & $1,5 \%$ \\
\hline
\end{tabular}

Sumber :data diolah peneliti (2020)

\section{Uji Kelayakan Model}

Nilai adjusted $R^{2}$ atau R (korelasi) sebesar 0,489 atau 48,9\%. Dari hasil tersebut viral marketing dan brand awareness memengaruhi niat beli pada Burger King Indonesia sebesar 48,9\% dan sisanya sebesar 0,511 atau 51,1\% menunjukkan niat beli dapat dipengaruhi oleh variabel lain di luar variabel viral marketing dan brand awareness yang tidak termasuk dalam penelitian ini.

\section{Hasil Uji Regresi Linier Berganda}

Analisis regresi linier berganda berguna untuk mengetahui pengaruh variabel viral marketing dan brand awareness terhadap variabel niat beli pada produk Burger King Indonesia. Hasil uji regresi linier berganda pada tabel 3 . 
Tabel 3.

HASIL UJI REGRESI LINIER BERGANDA

\begin{tabular}{lccc}
\hline \multicolumn{1}{c}{ Variabel } & Koefisien Regresi & Uji T & Signifikan \\
\hline (Constant) & -0.372 & -0.322 & 0.747 \\
Viral marketing & 0.262 & 7.038 & 0.000 \\
Brand awareness & 0.244 & 6.641 & 0.000 \\
\hline Sur :
\end{tabular}

Sumber :data diolah peneliti (2020)

Berdasarkan tabel 3, model persamaan regresi linier berganda dapat diperoleh persamaan (1).

$Y=-0,372+0,262 X 1+0,244 X 2$

Dari hasil persamaan (1) dapat diinterpretasikan bahwa nilai kontanta sebesar -0,372 dapat diartikan adanya tanda negatif pada konstanta menunjukkan apabila tidak terdapat variabel viral marketing dan brand awareness maka niat beli tidak terjadi pada Burger King Indonesia. Niat beli pada Burger King Indonesia yang dilakukan pelanggan tidak akan terjadi tanpa adanya faktor viral marketing dan brand awareness. Nilai koefisien variabel viral marketing sebesar 0,262, artinya apabila viral marketing yang diterima responden tentang niat beli Burger King Indonesia semakin banyak, maka niat beli responden akan semakin meningkat untuk membeli di Burger King Indonesia. Nilai koefisien variabel brand awareness sebesar 0,244. Artinya, semakin baik brand awareness Burger King Indonesia seperti logo, lokasi, dan menu makanan semakin meningkat dikalangan responden, maka akan semakin meningkatkan niat beli responden.

\section{Hasil Uji Hipotesis}

Tabel 3, hasil analisis regresi berganda (uji t) atau nilai t hitung untuk variabel viral marketing sebesar 7.038 dengan nilai signifikansi $0,000<0,05$. Terdapat pengaruh yang signifikan antara variabel viral marketing terhadap niat beli pada produk Burger King Indonesia. Selanjutnya, hasil variabel brand awareness sebesar 6.641 dengan nilai signifikansi $0,000<0,05$, sehingga antara variabel brand awareness terdapat pengaruh signifikan terhadap niat beli pada produk Burger King Indonesia.

\section{Pengaruh Viral marketing terhadap Niat Beli}

Kotler \& Keller (2016:647) menyebutkan bahwa viral marketing adalah salah satu faktor yang dapat memengaruhi niat beli. Viral marketing diharapkan memiliki multi efek karena banyak orang yang menerima pesan dapat menyampaikan kepada puluhan bahkan ratusan pengguna internet lainnya (Satrio et al., 2020). Liu dan Wang (2019) menyatakan viral marketing pada objek pesan viral marketing dari perusahaan berpengaruh terhadap niat beli. Pemasaran viral menggambarkan peran yang berguna dalam mengubah niat beli konsumen, dengan menggunakan alat atau teknik yang berbeda. Hal ini mengacu pada penyebaran luas teknologi di seluruh dunia, bidang pemasaran telah berkembang pesat; pelanggan adalah elemen dari proses pemasaran, di mana pelanggan menjadi target utama dari proses tersebut, sehubungan dengan keberadaan sosial media yang digunakan oleh hampir semua tingkatan dan usia orang dapat menjadi alat promosi penting untuk berbagai produk dan layanan (Sawaftah et al., 2019).

Hasil penelitian menunjukkan viral marketing memberikan pengaruh positif terhadap niat beli. Hasil ini sesuai dengan Rukuni et al. (2017). Trivedi (2017); Motwani \& Haryani (2018); dan Satrio et al (2020) juga menyatakan bahwa viral marketing berpengaruh secara signifikan terhadap niat beli. Hal ini sesuai dengan pendapat ahli yang mengartikan pendorong untuk memengaruhi tindakan seseorang memiliki niat membeli suatu produk salah satu faktor yaitu dengan adanya pengaruh viral marketing sehingga akan meningkatkan niat beli (Liu \& Wang, 2019).

Responden yang mendominasi pada penelitian ini adalah pada usia 19 - 29 tahun berjenis kelamin wanita, memiliki pekerjaan sebagai mahasiswa/pelajar, serta pengeluaran kurang dari Rp.1.000.000, 
Agatha Christy Avega Dumatri \& Tias Andarini Indarwati. Pengaruh Viral Marketing dan Brand Awareness terhadap Niat Beli pada Burger King Indonesia

di mana kategori ini responden secara kemampuan ramah dengan dunia digital dan memiliki lebih banyak waktu luang sehingga lebih banyak menghabiskan waktu dengan internet atau dunia digital. Pada usia tersebut, ingin mengetahui banyak hal baru sehinggan aktif dalam berinteraksi dengan satu sama lain. Hadirnya kecanggihan perangkat teknologi saat ini untuk mendapatkan referensi pilihan restoran fast food atau promo makanan, pada usia tersebut mendapatkan informasi dengan melihat pada postingan instagram resmi restoran, hal tersebut digunakan sebagai acuan calon pembeli. Sesuai dengan fokus pangsa pasar sasaran perusahaan saat ini yang menggunakan media sosial untuk melakukan promosi produk maupun layanannya (Sawaftah et al., 2019). Selain itu sesuai dengan data responden yang didominasi wanita, instagram merupakan platform yang paling diminati kaum wanita, hal ini dikarenakan kaum wanita memiliki kegemaran membicarakan sesuatu seperti pada kolom komentar instagram dan memiliki kegemaran belanja cocok dengan aplikasi instagram yang digunakan oleh perusahaan untuk mempromosikan produk (www.goodnewsfromindonesia.id, 2020).

Seperti yang disampaikan Kotler \& Keller (2016:647) viral marketing adalah versi internet dari pemasaran mulut-ke-mulut atau konten pemasaran yang melibatkan konsumen ingin menyebarkannya kepada orang lain. Maka pemasaran viral yang dilakukan Burger King Indonesia dengan membuat konten viral menyarankan pembelian pada merek lain, hal ini telah menjadi sebuah keunikan tersendiri. Konten instagram yang beda dari yang lain tersebut telah sesuai dengan dominasi responden penelitian ini yaitu anak muda saat ini yang suka membahas sesuatu hal tidak biasa sehingga konten tersebut menjadi viral. Perlu disoroti bahwa viral berbeda dengan trending, apabila trending maka topik tersebut diperbincangkan hanya pada satu platform dan waktunya terbatas sedangkan viral muncul diberbagai lintas platform seperti instagram, twitter, facebook, youtube, dan lain-lain (www.shukanbunshun.com, 2019).

Keseluruhan responden penelitian ini memercayai informasi yang ada di akun instagram resmi Burger King Indonesia. Hal ini dikarenakan instagram resmi Burger King Indonesia dikelola langsung oleh perusahaan sehingga informasi yang ada pada instagram tersebut dinilai akurat dan dapat dipercaya.

\section{Pengaruh Brand awareness terhadap Niat Beli}

Brand awareness atau ekuitas merek merupakan preferensi konsumen terhadap suatu produk (Lee \& Goh, 2019). Adanya pengaruh brand awareness dapat meningkatkan niat beli. Dengan melihat segala sesuatu yang terkait dengan merek tertentu, pelanggan dapat dengan mudah mengetahui dan mengenali produk (Walangitan et al., 2015). Hasil responden yang mendominasi penelitian ini adalah pada rentang usia 19 - 29 tahun atau anak muda yang lebih cepat menerima berbagai informasi perkembangan merek yang ada saat ini. Apabila konsumen punya kesadaran tentang suatu merek, mereka dapat dengan mudah mengingat beberapa karakteristik merek. Dengan demikian, selama proses pengambilan keputusan untuk membeli kategori produk tertentu, kemampuan mengingat merek sebagai anggota kategori produk akan meningkatkan probabilitas suatu merek untuk dimasukkan sebagai pertimbangan akan dibeli oleh konsumen (Lee \& Goh, 2019).

Dominasi karakteristik lain dari responden yaitu rata-rata berjenis kelamin wanita yang bekerja sebagai mahasiswa/pelajar sehingga memiliki banyak waktu luang dan memiliki gaya hidup yang suka nongkrong atau berkumpul bersosialisasi bersama teman-teman (pergikuliner.com, 2021). Kemudian dominasi responden memiliki pengeluaran kurang dari Rp.1.000.000, hal ini sesuai dengan harga produk yang ditawarkan Burger King Indonesia di mana harga yang ditawarkan relatif murah. Restoran fast food menyediakan berbagai jenis makanan fast food dalam satu paket menu yang ditawarkan dengan harga ekonomis sehingga banyak disukai konsumen (tribunnews.com, 2019). Susilowati \& Sari (2020) menyarankan dengan membangun brand awareness yang kuat seperti mengkomunikasikan nama, logo, variasi produk, meningkatkan pengemasan menjadi lebih menarik serta menciptakan cara unik bagaimana produk disajikan kepada konsumen. Hal tersebut akan menarik bagi konsumen dan membuat konsumen lebih mengingat suatu merek tersebut. Kotler \& Keller (2016:179) ada tiga peran kesadaran merek berperan dalam pengambilan keputusan konsumen, yang pertama itu meningkatkan kemungkinan pelanggan untuk memilih merek tertentu, yang kedua dapat memengaruhi pertimbangan jika pelanggan menghadapi beberapa pilihan, dan yang ketiga 
adalah memengaruhi pengambilan keputusan konsumen dengan memengaruhi pembentukan dan kekuatan merek.

Responden pada penelitian ini belum memilih Burger King Indonesia menjadi pilihan pertama (top of mind) untuk restoran fast food, hal ini terlihat dari hasil item pernyataan terkait top of mind namun tingkat brand awareness masyarakat pada merek Burger King Indonesia sudah pada tingkat brand recall, di mana responden telah mengetahui dengan baik tentang Burger King Indonesia tanpa bertanya kepada orang lain. Adanya paparan hasil pembahasan dan hasil penelitian menunjukkan bahwa terdapat pengaruh brand awareness terhadap niat beli secara signifikan, sehingga penelitian ini tidak mendukung Walangitan et al. (2015), Suryadi (2015) dan Koliby \& Rahman (2018). Namun penelitian ini mendukung hasil penelitian Soewandi (2015), Lee \& Goh (2019) dan Susilowati \& Sari (2020), brand awareness berpengaruh signifikan terhadap niat beli.

\section{KESIMPULAN}

Kedua hipotesis dalam penelitian diterima, yaitu variabel viral marketing dan brand awareness berpengaruh signifikan terhadap niat beli pada produk Burger King Indonesia. Pada penelitian ini viral marketing berpengaruh signifikan terhadap niat beli. Viral marketing yang dilakukan oleh Burger King Indonesia di instagram dapat dikatakan berhasil menarik calon konsumen. Variabel brand awareness berpengaruh signifikan terhadap niat beli. Jika brand awareness mengalami peningkatan, maka akan meningkatkan niat beli.

Dari hasil responden, Burger King Indonesia belum menjadi pilihan utama para calon konsumen di antara restoran fast food. Namun pesan Burger King yang viral terbukti mempengaruhi konsumen untuk membeli produk Burger King Indonesia. Ini berarti strataegi yang dilakukan melalui pesan yang out of the box menjadi salah satu strategi Burger King Indonesia untuk memengaruhi niat beli konsumen. Strategi Burger King Indonesia dengan memposting pesan out of the box berupa ajakan agar masyarakat membeli produk dari restoran fast food lainnya merupakan hal yang tidak biasa. Karena menarik maka pesan ini menjadi pembicaraan bahkan melintas diberbagai platform sosial media dan menjadi viral. Pesan ini menunjukkan a di masa pandemi yang sulit ini Burger King berempati dengan restoran lainnya. Hasil penelitian ini menunjukkan bahwa strategi viral marketing dan brand awareness memengaruhi niat beli konsumen. Perusahaan perlu memberikan perhatian khusus untuk dapat lebih bersaing di antara pesaing untuk dapat menjadi pilihan utama konsumen. Apabila perusahaan mampu melakukan hal tersebut konsumen akan memiliki top of mind untuk Burger King Indonesia di antara produk sejenis. Keterbatasan penelitian ini yaitu pengambilan data secara online dan hanya terfokus pada dua variabel saja sehingga saran untuk penelitian selanjutnya perlu dicari faktor-faktor lainnya selain dua variabel tersebut yang berpengaruh terhadap niat beli ataupun meneliti pada merek restoran fast food lain yang menjadi top of mind di masyarakat.

\section{DAFTAR PUSTAKA}

Auliani,P.(2020).Pertumbuhan Ekonomi Minus 5,32 Persen: Sekali Lagi, Tolong Kendalikan Pandeminya. (https://money.kompas.com/read/2020/08/06/122846926/pertumbuhan-ekonomiminus-532-persen-sekali-lagi-tolong-kendalikan-pandeminya?page=all, diakses pada 20 Desember 2020).

Durianto, D., Sugianto, \& Budiman, L. J. (2004). Brand Equity Ten Strategi Memimpin Pasar. Jakarta. Gramedia Pustaka Utama.

Febriani, Hani.(2020). Trending di Twitter, Aksi Solidaritas Burger King Ajak Warga Beli Produk McD, KFC, hingga Warteg. (https://www.pikiran-rakyat.com/ekonomi/pr-01910734/trendingdi-twitter-aksi-solidaritas-burger-king-ajak-warga-beli-produk-mcd-kfc-hingga-warteg, diakses pada 5 Desember 2020). 
Agatha Christy Avega Dumatri \& Tias Andarini Indarwati. Pengaruh Viral Marketing dan Brand Awareness terhadap Niat Beli pada Burger King Indonesia

Fendy.(2019).Viral dan Trending Adalag Dua Hal Berbeda. (https://www.shukanbunshun.com/2019/09/viral-dan-trending-adalah-duahal.html?m=1\#: :text=Perbedaan\%20Viral\%20dan\%20Trending\%20adalah,platform\%20dan\% 20waktunya\%20itu\%20terbatas, diakses pada 4 November 2020).

Iman, Mustafa. (2020). Pengguna Instagram di Indonesia Didominasi Wanita dan Generasi Milenial (https://www.goodnewsfromindonesia.id/2020/06/14/pengguna-instagram-di-indonesiadidominasi-wanita-dan-generasi-milenial, diakses pada 6 April 2021)

Kemp, S. (2020). Digital 2020: Indonesia. (https://datareportal.com/reports/digital2020-indonesia, diakses pada 1 februari 2021)

Koliby, A. L., \& Rahman, M. A. (2018). Influence Dimensions of Brand Equity on Purchase Intention Toward Smartphone in Malaysia. VFAST Transactions on Education and Social Sciences, 15(1), 7-19. https://vfast.org/journals/index.php/VTESS/article/view/478

Kotler, P., \& Keller, K. L. (2016). Marketing Management. (15e ed.). New Jersey: Pearson Pretice Hall, Inc.

Lee, J. E., \& Goh, M. L. (2019). Understanding purchase intention of university students towards skin care products. PSU Research Review, 3(3), 161-178. https://doi.org/10.1108/prr-11-2018-0031

Liu, H.-H., \& Wang, Y.-N. (2019). Interrelationships between Viral marketing and Purchase Intention via Customer-Based Brand Equity. Journal of Business and Management Sciences, 7(2), 72 83. https://doi.org/10.12691/jbms-7-2-3

Martins, J., Costa, C., Oliveira, T., Gonçalves, R., \& Branco, F. (2017). How smartphone advertising influences consumers' purchase intention. Journal of Business Research, 94(December 2017), 378-387. https://doi.org/10.1016/j.jbusres.2017.12.047

Motwani, B., \& Haryani, S. (2018). Investigating the Relation between Factors Effecting Viral marketing and Consumers' Buying Intention Evaluated by a double blind review system. European Journal of Applied Business Management, 4(2), 58-73.

Novika, Soraya. (2020). Burger King Minta Pelanggan Beli McDonald's Cs, Strategi Marketing? (https://finance.detik.com/berita-ekonomi-bisnis/d-5242223/burger-king-minta-pelanggan-belimcdonalds-cs-strategi-marketing, diakses pada 18 Mei 2021)

Pergikuliner.com. (2021). Kafe dan Tren Nongkrong Anak Muda. (https://pergikuliner.com/blog/kafedan-tren-nongkrong-anak-muda, diakses pada 21 April 2021)

Rukuni, T. F., Shaw, G., Chetty, Y., Kgama, P., Kekana, P., \& Rogers, K. (2017). Viral marketing Strategies and Customer Buying Behavioural Intentions at Retail Store in Johannesburg. Business Management and Strategy, 8(1), 59. https://doi.org/10.5296/bms.v8i1.10676

Sandi,F.(2020). Ada Apa dengan Burger King Minta Warga Pesan McD Hingga KFC?. (https://www.cnbcindonesia.com/news/20201105100701-4-199425/ada-apa-dengan-burgerking-minta-warga-pesan-mcd-hingga-kfc, diakses pada 25 November 2020)

Satrio, D., Priyanto, S. H., \& Nugraha, A. K. N. A. (2020). Viral marketing for cultural product: The role of emotion and cultural awareness to influence purchasing intention. Montenegrin Journal of Economics, 16(2), 77-91. https://doi.org/10.14254/1800-5845/2020.16-2.6

Sawaftah, D. A., Çalıcıoğlu, C., \& Awadallah, R. I. (2019). The relationship between viral marketing and consumer purchase intention, the moderator role of brand image and age: Evidence from 
smartphone users in North Cyprus. Management Science Letters, 10(6), 1307-1320. https://doi.org/10.5267/j.msl.2019.11.027

Setiawan,K. (2020). Dampak Wabah Virus Corona terhadap Pizza Hut dan KFC. (https://bisnis.tempo.co/read/1318477/dampak-wabah-virus-corona-terhadap-pizza-hut-dankfc/full\&view=ok, diakses pada 25 November 2020)

SI, S. (2016). Social Media and Its Role in Marketing. Business and Economics Journal, 07(01), 1-5. https://doi.org/10.4172/2151-6219.1000203

Soewandi, M. (2015). The impact of Social Media Communication on Brand awareness, Brand Equity and Purchase Intention. Interaksi Online, 3(2), 204-213.

Suryadi, D. (2015). The Impact of Brand Equity towards Purchase Intention on PT . X' s Candy. IBuss Management, 3(2), 1-8.

Susilowati, E., \& Sari, A. N. (2020). (ijm\&p). February, 39-53. https://doi.org/10.14807/ijmp.v

Topbrand-award.com. (2020). Top Brand Award Restoran Fastfood 2018-2020. (https://www.topbrand-award.com/top-brand-index/?tbi_find=Burger\%20King. Diakses pada 25 November 2020)

Tribunnews.com. (2019). Alasan Umum Kenapa Junk Food Disukai Banyak Orang, Padahal Tidak Sehat. (https://www.tribunnews.com/kesehatan/2019/08/30/alasan-umum-kenapa-junk-fooddisukai-banyak-orang-padahal-tidak-sehat?page=, diakses pada 21 April 2021)

Trivedi, J. P. (2017). The Effect of Viral marketing Messages on Consumer Behaviour. Business, Management and Economics Research, 17(2), 84-98. https://doi.org/10.32861/bmer.65.58.66

Kbbi.kemdikbud.go.id. 2020. Viral (Def.1 dan 2) (n.d) dalam Kamus Besar Bahasa Indonesia (KBBI) Online. (https://kbbi.kemdikbud.go.id/entri/viral, diakses pada 20 Desember 2020).

Walangitan, A., Pangemanan, S., \& Rumokoy, F. (2015). Analysing the Impact of Brand Equity on Consumer Purchase Intention of Etude House Cosmetic Product in Manado. Jurnal Riset Ekonomi, Manajemen, Bisnis Dan Akuntansi, 3(2), 758-766. https://doi.org/10.35794/emba.v3i2.8898

Wiludjeng, S., \& Nurlela, T. S. (2013). Pengaruh Viral marketing Terhadap Keputusan Pembelian Pada PT "X." Proceeding Seminar Nasional Pengaruh Viral marketing Terhadap Keputusan Pembelian Pada Pt "X," l(Viral marketing), 978-979. http://publikasiilmiah.ums.ac.id:8080/handle/123456789/3838.

Yoo, B., Donthu, N., \& Lee, S. (2000). An examination of selected marketing mix elements and brand equity. Journal of the Academy of Marketing Science, 28(2), 195-211. https://doi.org/10.1177/0092070300282002 